Davin L. Helkenberg

Western University, London, Ontario, Canada

\title{
Young Women Encountering Information on Sexuality in Young Adult Literature
}

\begin{abstract}
This paper investigates Young Adult (YA) Literature as a source of information on sexuality for young women readers. The data for this study is derived from semi-structured interviews (Seidman, 2006) that were conducted with 11 female participants. Six major categories of information on sexuality were found within the interview data: sexual acts, types of relationships, relationship realities, strategies for dealing with relationship problems, sexual abuse, and consent. These findings provide empirical evidence that YA Literature can act as a valuable source of information on sexuality and may promote the sexual agency and well-being of young people, especially young women.
\end{abstract}

\section{Introduction}

This paper seeks to contribute to the study of fiction as a source of everyday life information. Specifically, it investigates Young Adult (YA) Literature as a source of information on sexuality for young women readers. Through the examination of the reading experiences and practices of eleven young women who read sexuality-themed YA Literature, this paper identifies six major informational topics on sexuality that can be found in YA Literature. It also argues that the type of information that can be found can help fill in the gaps of traditional sex education and contribute to the sexual wellbeing of young people.

\section{Literature Review}

A link between fiction reading and Everyday Life Information Seeking (ELIS) has been well established in Library and Information Science (Moyer, 2007; Ooi \& Liew, 2011; Ross, 1999, 2000; Usherwood \& Toyne, 2002). Most prominently, Catherine Ross’ (1999, 2000) seminal research on finding without seeking was the first to draw links between fiction reading and ELIS. Ross found that although readers of fiction did not necessarily see themselves as actively seeking information, they were able to find valued information in fiction that informed their everyday lives. According to Denise Agosto and Sandra Hughes-Hassell (2006a, 2006b), in the ELIS behaviour of teens, teens are motivated to seek information to develop the following set of variables that directly relate to their maturation process: the social, emotional, reflective, physical, creative, cognitive, and sexual self. In general, scholars such as Paulette Rothbauer (2006) and Vivian Howard (2011) have found that reading fiction offers young people an opportunity to learn more about their social worlds, their places within it, and the possibilities for them in the future. Although sexuality is one of the major variables in teen ELIS, and some scholars such as Amy Pattee (2006), Judith Levine (2002), and Jen Gilbert (2004) have specifically suggested literature as a source of information on sexuality for young people, very few major empirical studies have been conducted on the reading practices and experiences of young readers in relation to sexuality. ${ }^{1}$

\section{Methodology}

The data for this study is derived from responses from phenomenological semi-structured interviews (Seidman, 2006) that were conducted with 11 female participants for the author's doctoral thesis research. ${ }^{2}$ Participants were between the ages of 18 and 24 and attended Canadian post-secondary institutions. During the interviews (45 to 90 minutes in length), participants were asked about their current and past reading experiences. Each participant varied in the type of texts they read, 
relationship or sexual experience, sexual orientation, and ethnicity. ${ }^{3}$ Types of texts read included novels, comics, and fanfiction. ${ }^{4}$ Novels included quintessential YA texts such as Judy Blume's Forever (1975) and John Green's Looking for Alaska (2005). Comics included stories of adolescence such as The Diary of a Teenage Girl by Phoebe Gloeckner (2002) and Japanese comics such as Kiss Him, Not Me by Junko (2013-2018). Fanfiction included a wide variety of fanworks including Harry Potter, Percy Jackson, One Direction and Hunger Games fanfictions. Thematic analysis (Braun \& Clarke, 2006) was used to identify, analyse and report themes found within the interview data.

\section{Findings}

Six major categories of information on sexuality were found within the interview data. Listed in descending order of most frequently referenced to least frequently referenced, each of these categories were referenced by at least two of the eleven participants.

\section{Sexual Acts}

Arya: I remember that the characters were trying to have oral sex and it was just bizarre to me. Straight up bizarre...it kind of broadened my horizons in that sense where I was like, ok...I guess sex doesn't have to be penis in vagina.

Participants learned three types of significant details about sexual acts from YA Literature:

1) It introduced them to new sexual acts such as different sexual positions, non-penetrative sex (oral/digital), and sex in different contexts (not just in a bed).

2) It taught them the mechanics of sexual acts. For example, how oral sex is performed.

3) It presented sexual acts as pleasurable as opposed to strictly reproductive.

\section{Types of Relationships}

Sarah:...there was always this, not a stereotype but a connotation that you're not really a lesbian, you're only doing this because you can't find a man or scared of a man...And after reading this literature I found that it's possible to be in a relationship with another female. And even though they don't have a penis, it doesn't make it any less authentic.

Participants reported that YA Literature taught them about different types of relationships. Foremost, this was in reference to LGBTQ relationships. However, it also extended to the possibility of other non-normative relationships such as incestuous or age-gap relationships.

\section{Relationship Realities}

Stacey: [I learned about]...the intimacy of sexual intercourse. Because your parents can tell you, or forbid you... and the textbooks can tell you the technicalities. But, it's different when you see a character go through it and what they learn and what they regret...That it's not just technical terms. It's not just feelings or what your parents tell you. There can be pros and cons to every romantic or intimate sexual relationship.

Participants reported that YA Literature presents a broader and more realistic picture of what relationships are like in practice: how people meet, start dating, engage in sex, and face obstacles together.

\section{Strategies for Dealing with Relationship Problems}

Andie: ...I would read a story and I would be like, "Oh my god, why would he even get mad about that?" And then I'd think about it and like, wait, that's happened to me and I completely overreacted. Seeing it from the other side in a situation that wasn't mine...I was like, "Oh, I could see it now, I guess". I have a bank of information that I can draw on and 
say, ok, I can either respond to this this way, like what I want to do right now, or I have five other stories that I had just read.

Participants reported that reading about characters who were going through difficult situations in their sexual or romantic relationships provided examples of how to deal with their own relationship problems or reflect on their own personal issues that affect their relationships.

\section{Abusive Relationships}

Bonnie: So, when I was in the beginning of high school...[the book] was called Beach Blonds. There was this girl, she was taking the summer in the Florida Keys with her family. Everything was going nice. There were beautiful girls running on the beach, everything was fine, she met guys...but then it hit a point in the book where a friend of hers, she was in an abusive relationship...And it made me take a step back and consider maybe sex isn't that simple.

Participants reported that YA Literature taught them about different aspects of abuse. Predominantly, it provided nuanced examples of what abusive relationships can look like. In some cases, it also provided opportunities for participants to reflect on what it means to be treated well in a relationship.

\section{Consent}

Arya: I remember reading this book called Speak, it was about this story about this girl who got raped....So, I think, it was kind of like one of those moments for me where sex didn't equal pleasure. Or sex didn't equal baby. It was this whole other darker dimension that I had no idea about. And it got me thinking about the ownership of your body, consent, and all the other very vital things that come with the idea of sex.

Consent was often discussed in relation to instances of rape, where consent was violated and in turn readers thought about what it means to give consent or have to ownership over one's body.

\section{Discussion}

These findings provide empirical evidence that YA Literature can act as a valuable source of information on sexuality for young people, especially young women. Moreover, the inclusion of information on sexual pleasure, non-normative sexual relationships, and consent are especially significant as many sex education scholars have identified this information as missing from formal sex education (see for example Allen, 2004; Cameron-Lewis \& Fine, 2013; Fine, 1988; Gilbert, 2018). They argue that this information may ultimately contribute to the sexual empowerment of young people, especially young women, by validating dynamic sexual feelings and acknowledging sexual agency. Some participants in this study reported that YA Literature was their primary source of information on the social, emotional, and pleasurable components of sexual relationships, but participants also emphasised that this source is best used in alongside traditional forms of sex education such as school curricula, textbooks, and health information.

It is also important to note that while these participants talked about a wide range of information on sexuality found in YA Literature, some participants also felt that YA Literature as a whole did not contain the information that they were seeking. This included positive narratives about LGBTQ relationships, BDSM play, and more descriptive sex scenes. The lack of this type of content is due to limitations on what is considered appropriate sexual knowledge for young readers. Prominent scholars in YA Literature Studies have written on this dilemma and have identified problematic codes and tropes found within narratives of sexuality in YA Literature that promote sexual repression (ChristianSmith, 1990; Kokkola, 2013; Trites, 2000). In effect, YA Literature often schools readers on sexuality according to adult viewpoints and does not necessarily portray teen sexuality honestly. Due to this limitation, YA Literature may not meet some readers’ sexual information needs. Future research that 
explores the positive and problematic aspects of YA Literature within the context of the reading needs to be conducted.

\section{Conclusion}

This paper reveals the informative value of sexuality-themed YA Literature in the context of everyday life. In sum, YA Literature has the potential to give a more nuanced portrayal of sexuality that goes beyond the biological and includes the social, emotional, pleasurable, and painful aspects of sexual relationships that are traditionally excluded from sex education. This finding can provide a starting point for considering how YA Literature can be used in educational settings as well as how narratives of sexuality in fiction can be improved to better meet the informational needs of young readers.

\footnotetext{
${ }^{1}$ Major exceptions include Linda Christian-Smith (1990) and Paulette Rothbauer (2004).

${ }^{2}$ This study was reviewed and approved by the Western University Non-Medical Research Ethics Board.

${ }^{3} 7 / 11$ self-identified as a person of colour. 3/11 self-identified as bisexual, pansexual, or lesbian.

${ }^{4}$ Young Adult Literature is defined for this study as literature in any form that is written about teens and written in a teen voice.
}

\section{Reference List:}

Agosto, D. E. \& Hughes-Hassell, S. (2006a). Toward a model of the everyday life information needs of urban teenagers, part 1: Theoretical model. Journal of the American Society for Information Science and Technology, 57(10), 1394-1403.

Agosto, D. E. \& Hughes-Hassell, S. (2006b). Toward a model of the everyday life information needs of urban teenagers, part 2: Empirical model. Journal of the American Society for Information Science and Technology, 57(11), 1418-1426.

Allen, L. (2004). Beyond the birds and the bees: Constituting a discourse of erotics in sexuality education. Gender and Education, 16(2), 151-167.

Braun, V. \& Clarke, V. (2006). Using thematic analysis in psychology. Qualitative Research in Psychology, 3(2), 77-101.

Cameron-Lewis, V. \& Allen, L. (2013). Teaching pleasure and danger in sexuality education. Sex Education, 13(2), 121-132.

Christian-Smith, L. K. (1990). Becoming a woman through romance. New York: Routledge.

Fine, M. (1988). Sexuality, schooling , and adolescent females: The missing discourse of desire. Havard Educational Review, 58(1), 29-53.

Gilbert, J. (2004). Literature as sex education. Changing English, 11(2), 233-241.

Gilbert, J. (2018). Contesting consent in sex education. Sex Education, 18(3), 268-279.

Howard, V. (2011). The importance of pleasure reading in the lives of young teens: Selfidentification, self-construction and self-awareness. Journal of Librarianship and Information Science, 43(1), 46-55.

Kokkola, L. (2013). Fictions of adolescent carnality: Sexy sinners and deliquent deviants. Amsterdam: John Benjamins Publishing Co.

Levine, J. (2002). Harmful to minors: The perils of protecting children from sex. Minneapolis: University of Minnesota Press.

Moyer, J. E. (2007). Learning from leisure reading: A study of adult public library patrons. Reference \& User Services Quarterly, 46(4), 66-79.

Ooi, K. \& Liew, C. L. (2011). Selecting ficton as part of everyday life information seeking. Journal of Documentation, 67(5), 748-772.

Pattee, A. (2006). The secret source: Sexually explicit young adult literature as an information source. Young Adult Library Services, 4(2), 30-38.

Ross, C. S. (1999). Finding without seeking: The information encounter in the context of reading for pleasure. Information Processing \& Management, 35(6), 783-799.

Ross, C. S. (2000). Finding without seeking: What readers say about the role of pleasure reading as a source of information. Aplis, 13(2), 72-81. 
Rothbauer, P. M. (2004). Finding and creating possibility: Reading in the lives of lesbian, bisexual and queer young women. Unpublished dissertation, University of Western Ontario, London, Canada.

Rothbauer, P. M. (2006). Young adults and reading. In C. S. Ross, L. E. F. McKechnie, \& P. M. Rothbauer, Reading matters: What the research reveals about reading, libraries, and communities, (pp. 101-127). Westport, CN: Libraries Unlimited.

Seidman, I. (2006). Interviewing as qualitative research: A guide for researchers in education and the social sciences (3rd ed.). New York: Teachers College Press.

Trites, R. S. (2000). Disturbing the universe: Power and repression in adolescent literature. Iowa City: University of Iowa Press.

Usherwood, B. \& Toyne, J. (2002). The value and impact of reading imaginative literature. Journal of Librarianship and Information Science, 34(1), 33-41. 